\title{
The Electoral Effects of General Strikes in Western Europe
}

\author{
Kerstin Hamann, Alison Johnston, and John Kelly
}

Since the 1980s, general strikes have occurred in Western Europe with increasing regularity. This increase has been particularly evident since the onset of the recent European debt crisis, during which general strikes have served as pivotal instruments of mass mobilization against austerity. General strikes are national work stoppages called by one or more national union confederation(s) against the government in its role as a legislator; more simply, they are mobilization events undertaken by unions when governments propose and/or introduce welfare or social policy reforms. Despite the increase in general strikes across Western Europe, we still know little about their effectiveness in holding governments accountable.

Governments' decisions to include labor unions in negotiating broadly unpopular policy reforms have resulted in numerous social pacts in Western Europe since the 1980s, providing the empirical basis for studies aiming to understand what motivates governments and social partners to cooperate. ${ }^{1}$ Much of the research has focused on "blame avoidance," understanding pacts as a way in which governments attempt to blunt the potential electoral backlash of unpopular reforms. Yet, at the same time governments' contentious policies have also been met with resistance from unions via general strikes: between 1980 and 2012, 130 general strikes or strike threats were recorded in eleven countries of the EU15 plus Norway.

We argue that, in contrast to social pacts, general strikes are tools of "blame attribution"; they express widespread protest against unpopular reforms and serve as a highly visible opportunity of blaming governments. We therefore ask whether general strikes carry electoral consequences. We employ a (quasi-differenced) panel regression to analyze the electoral effects of general strikes for governing parties between 1980 and 2012 for the EU15 plus Norway. Our results indicate that general strikes are associated with significant vote share declines for parties heading the executive and that these strikes magnify the impact of welfare retrenchment on incumbent vote loss. Unilateral welfare reforms in the absence of strikes produce no consistent, significant electoral repercussions for incumbents, while social pacts are associated with significant 
vote share gains for incumbents and dampen the negative electoral impact of welfare state retrenchment.

\section{General Strikes, Policy Reforms, and Elections}

Unlike social pacts, which have been identified as instruments of blame avoidance for unpopular policy reforms ${ }^{2}$ and signals for inclusive policy platforms in electoral races, ${ }^{3}$ general strikes have not been directly linked, either empirically or theoretically, to electoral outcomes. We therefore seek to provide a framework for whether, and how, this type of mass protest influences electoral outcomes.

General Strikes in Western Europe While economic (industrial) strikes targeting private employers have markedly declined in Western Europe since the $1980 \mathrm{~s},{ }^{4}$ general strikes have occurred with increasing frequency during the same time period (see Figure 1). Our definition of general strikes follows Hyman; we conceptualize a general strike as "a temporary, national stoppage of work by workers from many industries, directed against the executive or legislative arms of government, to enforce a demand or give voice to a grievance" (emphasis added by the authors). ${ }^{5}$ General strikes are a

Figure 1 General Strike Frequency in the EU15 plus Norway (1980-2012)

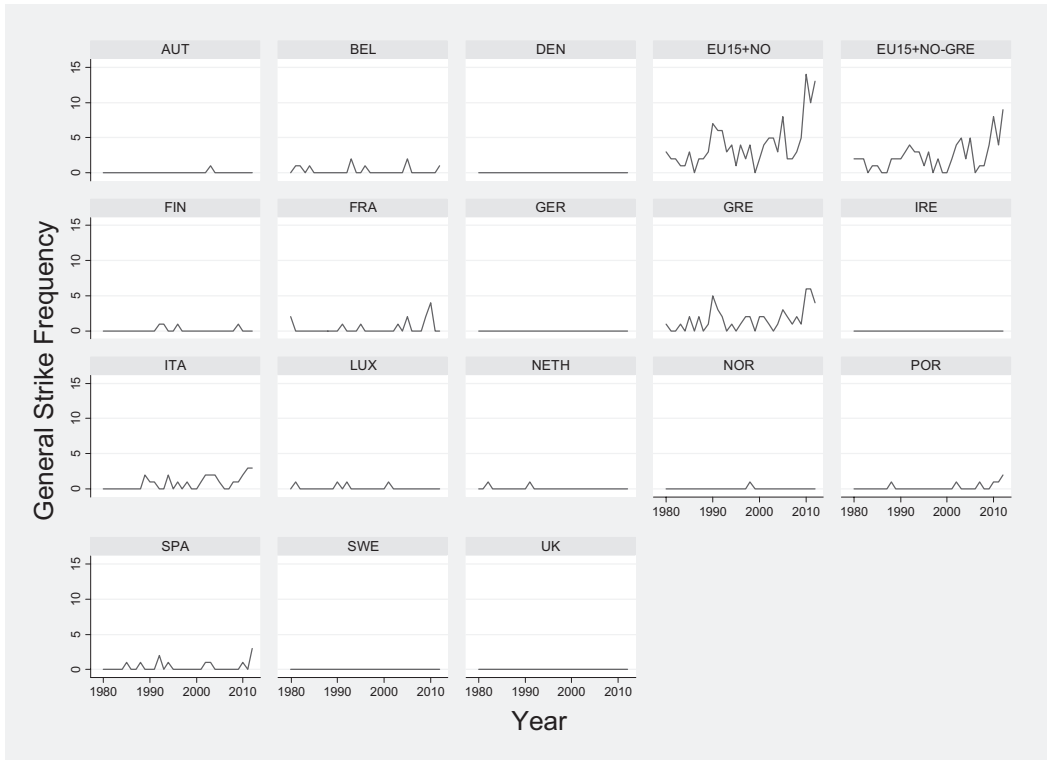

Source: Hamann, Johnston, Kelly (2013a) updated to 2012 from EIRO and Labour Research. 
reaction to governments' reform proposals and are only called when unions oppose contentious reforms. Organized by national union confederations, they mobilize not just union members, but also the population more generally. Scholarship on general strikes predominantly focuses on the national level and excludes stoppages by public sector employees protesting against the government in its capacity as employer and national demonstrations against government policies that do not include a general workers' strike. ${ }^{6}$

Since 1980, Western Europe has experienced a growing number of general strikes and strike threats: nineteen in the 1980s, thirty-six in the 1990s, thirty-nine between 2000 and 2009, and thirty-six between 2010 and 2012. ${ }^{7}$ While the majority of these strikes and strike threats have occurred in five countries that have high frequencies of economic strikes (Greece, France, Italy, Spain, and Portugal), they have also featured in countries with strong traditions of corporatism and industrial peace, including Belgium (nine strikes), Finland (four), and Luxembourg (four). Only five countries have not experienced any general strikes since 1980: Denmark, Germany, Ireland, Sweden, and the UK (general strikes against government are unlawful in Germany and the UK).

Governmental policy reforms targeted by general strikes fall into five categories: state pensions, welfare (non-pension social insurance, such as unemployment, sickness, and disability insurance), national wage policy (e.g., reform of minimum wages or the imposition of a national wage freeze), labor law (e.g., changes in dismissal legislation, nature of collective bargaining, or working time), and discretionary fiscal policy (e.g., the privatization of national industries, taxation policy, or cuts in public expenditure that are not entitlement programs). ${ }^{8}$ General strikes deviate from economic strikes as they target policies that are more encompassing in nature and hence may enhance sympathies from large segments of the population, rather than industry or firm-specific employment conditions, which may be directed more exclusively towards union members.

Declines in economic strikes, coupled with decreases in union density and membership, a declining wage share in national income, ${ }^{9}$ and in some cases also a drop in collective bargaining coverage, indicate an overall weakening of labor unions. Others have extended these trends to the political arena, arguing that unions are no longer politically relevant, as their legitimacy and threats of economic protest have declined substantially. ${ }^{10}$ While the claim that union power has decreased in the economic arena finds strong theoretical and empirical support, the frequency of general strikes raises the question as to whether they enhance unions' political clout by enabling them to penalize governments electorally. General strikes are important because they are targeted towards salient and encompassing social programs/issues, are economically costly, and, therefore, may impose political costs. ${ }^{11}$ Systematic analyses of the political costs of general strikes, however, are lacking. This study enhances our understanding of the political costs of such strikes by examining their electoral impact on incumbents. Existing research on the motivation for the rising number of general strikes, as well as that on welfare-state retrenchment, may provide some clues about their potential electoral impact. 
The Political Determinants of General Strikes Research on general strike incidence has emphasized the importance of political and industrial relations variables in instigating strikes. Lindvall focuses on industrial relations variables and finds that general strikes are most likely at moderate levels of union density. ${ }^{12}$ Others have examined the political determinants of general strikes and report that they are more likely to be called against conservative, single-party majority governments that exclude unions from policymaking under conditions of high unemployment and low economic growth. ${ }^{13}$ The mere existence of general strikes does not imply that they are effective in influencing policies as they could be ignored by governments. However, between 1980 and 2009, after general strikes, unions have secured concessions from governments in the form of reform alterations in 40 percent of cases. ${ }^{14}$

While these studies propose some reasons for why general strikes take place, we still know little about whether strikes produce electoral consequences. The prospect of such penalties may help explain why governments make concessions after general strikes or try to avoid them entirely by engaging in concertation with social partners on unpopular reforms via social pacts. Although blame avoidance has been extensively covered in the social pacts literature, ${ }^{15}$ it has not been extended to general strikes. General strikes are tools of blame attribution, rather than blame avoidance, as they underscore the responsibility of the government in planning or implementing reforms. Therefore, general strikes are likely to produce opposite electoral outcomes of social pacts.

Welfare Reforms, General Strikes, and Electoral Outcomes Existing literature provides mixed evidence on the electoral consequences of welfare state retrenchment. Some studies find that welfare state resilience can be attributed to its widespread public appeal. ${ }^{16}$ Voters' dissatisfaction with welfare state reform can be a determining factor for their political orientations and behavior; such dissatisfaction may hamper the likelihood of governments retaining their power in the event that they engage in retrenchment. ${ }^{17}$ Other studies find that electorates reward governments for increasing spending, ${ }^{18}$ although much of this literature emphasizes the myopic nature of voters, who are more likely to reward recent policy benefits and penalize recent policy blunders. ${ }^{19}$ Others, however, question the general link between welfare retrenchment and electoral punishment and analyze the significance of a range of intervening variables. ${ }^{20}$ Armingeon and Giger report no overall association between welfare cuts and vote loss, but rather find that vote losses occur where welfare cuts were large and constituted a salient issue in the election campaign. ${ }^{21}$ Furthermore, the scale of potential vote loss following retrenchment also depends on governments' strategies to implement welfare cuts and thereby pursue "blame avoidance." 22 Governments may act strategically in organizing reforms and in their communication in the public sphere in order to preempt and counteract potential electoral costs. ${ }^{23}$

Welfare reform literatures posit that governments may face electoral challenges if their reforms target popular programs or produce adverse economic outcomes. Because general strikes highlight unpopular reforms and hence may shape public 
sentiment, these forms of protest may provide a means for unions to influence governments' electoral support. Political and electoral factors affect the likelihood that unions stage general strikes; similarly, these factors also condition the likelihood that governments grant concessions in response to general strikes. ${ }^{24}$ It thus seems logical that general strikes affect the extent to which voters hold governments accountable for unpopular reforms, else governments would have little reason to grant strike concessions to unions. General strikes are relatively rare and highly visible events; their mobilization potential is high, and they can involve hundreds of thousands of participants. ${ }^{25}$ The question is thus whether these mass mobilizations that highlight painful reforms and directly target the government as the responsible actor produce or magnify electoral penalties for incumbents.

General strikes may have an impact on electoral outcomes via several mechanisms. First, the fact that a large number of (potential) voters find it necessary to demonstrate against the government and its policies might signal to the general electorate that the government enacts policies that go against its aggregated preferences. Brooks and Manza outline that citizens' aggregate policy preferences are a significant determinant behind welfare state persistence; general strikes may serve as a mechanism to draw attention to governments' moves against these preferences. ${ }^{26}$ Second, economic voting literature has highlighted that voters' "subjective economic perception" of macroeconomic conditions matters for their choices at the ballot box. ${ }^{27} \mathrm{We}$ posit that general strikes can affect voters' subjective perceptions of the economy and of policy reforms because they can underscore the severity of reforms. As Armingeon and Giger state in reference to welfare reforms, "Voters were alerted only when the dogs barked. And in most instances, the dogs did not bark. ${ }^{28}$ General strikes can play the role of the "barking dog" and thus increase issue salience, which can lead to electoral punishment.

Kriesi similarly finds evidence that the "ongoing process of political mobilization ... interacts with the electoral process in complex ways. ${ }^{29} \mathrm{He}$ argues that public protest, of which general strikes are part, "is designed to unleash a public debate, to draw the attention of the public to the grievances of the actors in question, to create controversy where there was none, and to obtain the support of the public for the actors' concerns." ${ }^{30}$ Kriesi also shows that widespread popular protests against austerity measures are linked to electoral backlash against governing parties. ${ }^{31}$ General strikes are highly visible, often most pronounced in densely populated urban areas and, consequently, gain widespread media coverage. A contentious reform may receive more attention on the part of the voters if unions call a general strike to highlight its terms, which, in turn, may influence voters' future electoral behavior. ${ }^{32}$ General strikes that occur close to an election may also have a stronger impact on the government's electoral performance than those that happened further removed in time. ${ }^{33}$ When the memory of a general strike and the unpopular reforms that prompted it is fresh, we expect voters to be more likely to adjust their vote choice. In contrast, voters may have less vivid memories of mass mobilizations in protest against the government's unpopular reforms if these events occurred early within an electoral cycle. 
In sum, we hypothesize that general strikes, as tools of blame attribution, have a negative effect on incumbent vote share and magnify the negative electoral impact of welfare retrenchment; additionally, these negative electoral effects are likely to become larger the closer a strike is called to an election. In contrast, social pacts, as tools of blame avoidance, are likely to have a positive effect on incumbents' vote shares and may blunt the negative electoral impact of retrenchment. Proximity is also likely to matter for pacts; these positive effects may be stronger the closer this vehicle of concertation happens to an election.

\section{Data, Variables, and Methods}

To examine the influence of general strikes on governments' reelection chances, we select election years as our unit of analysis. Our panel consists of the EU15 plus Norway, which provides a suitable combination of cross-national variation in industrial relations, union strength, and party systems coupled with variation in social and welfare policies. We analyze the 140 election years that occurred within these countries between 1980 and 2012; our country panels had, on average, eight election years in this thirty-three-year period, with Denmark having the most (eleven) and Luxembourg the least (six). Because we are interested in whether the electorate penalizes governments for general strikes at the ballot box, we ignore changes in governments that occur between elections or shifts to technocratic governments.

Measuring General Strikes, Unilateral Legislative Reform, Social Pacts, and Welfare Retrenchment We identify and empirically examine four possible scenarios of welfare retrenchment. First, absent in existing welfare literature, are governments' unilateral welfare reforms that result in general strikes. The second scenario is unilateral welfare reforms that do not result in general strikes (what we call "strikeless" unilateral legislation). Third are reforms that governments conduct in concertation with unions via social pacts. The fourth scenario, serving as our baseline category in the analysis below, is no reform.

While economic (industrial) strikes are frequently measured in number of working days lost, data on the number of days lost or workers involved in general strikes are unreliable and not available for our entire sample. Instead, we use frequencies to record general strikes. Data on general strikes were taken from Hamann, Johnston, and Kelly, Labour Research, the European Industrial Relations Review, and the European Industrial Relations Observatory; source details for each strike, as well as for social pacts and legislation, can be found online on the authors' website. ${ }^{34}$ Between 1980 and 2012, 117 general strikes $^{35}$ and thirteen credible strike threats (not resulting in an actual strike) occurred in the EU15 and Norway. We exclude general strike threats from our empirical analysis because they are far less visible to voters than actual strikes and lack strikes' mobilizing and valence effects. Because conceivably the exclusion of general strike threats may skew our results in favor of losses 
in incumbent vote share - as they are more likely to result in revised reform proposals - we also conducted our analysis including strike threats. Their inclusion left our findings largely unchanged; we therefore do not present those results here.

Out of the 140 election years in our sample, thirty-eight experienced reforms resulting in general strikes under the incumbent's most recent tenure. We select two manifestations of general strikes as our primary independent variable of interest. First, we use a binary indicator for whether a general strike has occurred during a government's tenure; an election year is coded 1 if a general strike occurred within the incumbent's tenure since the previous election, 0 if otherwise (columns I-II, Table 1; columns I and III, Table 2). ${ }^{36}$ Second, to determine whether strikes that are closer to elections prompt greater electoral penalties for incumbent governments, we included the time between the most recent general strike and the subsequent election. Our measure of strike proximity follows Ahlquist's measure of social pacts proximity-the number of months of the most recent general strike from the previous election divided by the country's constitutionally mandated electoral term (columns III and IV, Table 1; columns II and IV, Table 2). ${ }^{37}$ The value of this variable is between 0 and 1 (i.e., if the most recent general strike occurred three-quarters into an incumbent's term, it would take the value of 0.75 ).

While we are most interested in the electoral consequences of general strikes, we do not estimate their impact on election outcomes in isolation, as one could argue that the contentious policy reform rather than the resulting strike drives changes in an incumbent's vote share. Consequently, we employ two different techniques to partially offset this spurious correlation problem. First, we compare general strikes targeted towards governments' unilateral reforms against instances of strikeless unilateral legislative reform (our second reform scenario), which may receive less public visibility. This comparison allows us to disentangle the impact of unilateral reforms from the impact of general strikes. Although unilateral legislative reforms that do not precipitate strikes may involve retrenchment that is less contentious, using strikeless unilateral legislation as a benchmark enables us to compare welfare reform in countries where general strikes are illegal, and hence where unions lack the capacity to mobilize against government policies (of the sixty election years that contained strikeless unilateral legislation, twelve were in Germany and the United Kingdom, where general strikes are unlawful).

Instances of strikeless unilateral welfare reform exhibit greater frequencies during electoral cycles than general strikes and, unlike general strikes, are more evenly distributed amongst the EU15 plus Norway; between 1980 and 2012, ninety-four cases of strikeless unilateral legislation were initiated by governments (longitudinal graphics of strikeless legislation and social pacts are available in an appendix on the authors' website). In our regressions, we control for strikeless unilateral reform using the same two manifestations as we do for general strikes: a binary variable for whether a unilateral reform without a subsequent strike occurred within an incumbent's tenure and the number of months of the most recent strikeless legislative reform from the previous election divided by the country's constitutionally mandated electoral term. 
A second means to overcome the spurious correlation problem involves incorporating interactions between welfare state retrenchment and general strikes within our models. A serious limitation of the general strikes data is their lack of information on the severity of the reforms they target. To examine whether general strikes have distinct electoral effects independent of the scale of social policy retrenchment and whether they magnify the electoral effects of retrenchment, we interact strikes with three different proxies of welfare state rollback:

1.) changes in public expenditure on social benefits and transfers-in-kind (as a percent of GDP) between electoral cycles (our primary measure of retrenchment, columns I-IV, Table 1);

2.) changes in Scruggs' et al. ${ }^{38}$ social benefit generosity index (we average the pensions, unemployment, and sickness insurance generosity scores) between election cycles (columns I-II, Table 2), and;

3.) the residual of social expenditure regressed on unemployment, GDP growth, and the share of the elderly in the total population (columns III-IV, Table 2). We include this measure as a robustness check because changes in social expenditure between elections may be driven by demographic and business cycle changes, and not solely by discretionary fiscal (consolidation) policy; the residual of social expenditure regressed on unemployment, GDP growth, and the share of the elderly removes these non-discretionary factors that influence social spending changes.

We prioritize changes in social expenditure as our measure for welfare retrenchment, rather than Scruggs' et al. generosity index because general strikes are targeted at social policy retrenchment beyond pensions, unemployment insurance, and sickness insurance. Cuts in healthcare expenditure, housing benefit, education, and public infrastructure spending, for example, may also have wide public appeal, and hence general strikes against these issues may cater to voter discontent with incumbent governments. Because the Scruggs et al. index captures retrenchment in only two of the five strike issues (pensions and welfare), we interact only general strikes targeting pension and welfare reforms with changes in the social insurance generosity index within the models where this index proxies welfare state retrenchment (columns I-II, Table 2).

In addition to assessing the influence of general strikes and strikeless unilateral legislation on electoral outcomes, we also examine social pacts' electoral effects (our third scenario of welfare reform). Social pacts, bi- or tripartite national-level agreements between unions, employers, and governments on policy reform, ${ }^{39}$ provide a contrast in union-government exchange to general strikes, as unions are consulted and included in the reform process, and may therefore have the capacity to recommend alterations that defray these reforms' negative impact. ${ }^{40}$ Hence, unlike general strikes, which may increase electoral backlash for welfare retrenchment, social pacts may buffer the electoral repercussions of declines in social spending. Social pacts exhibit similar frequencies as general strikes in our sample, and, like strikeless unilateral 
legislation, are more evenly distributed among our sample countries; between 1980 and 2012, 124 social pacts were concluded between unions and governments, 55 of these were signed in the 1990s and 49 since 2000. Of the 140 elections, 68 were preceded by social pacts. We control for social pacts using the same two manifestations as for general strikes and strikeless unilateral legislation. Data on social pacts and legislation are from Hamann and Kelly, ${ }^{41}$ the European Industrial Relations Review, and the European Industrial Relations Observatory; further details are available in the online data appendix. ${ }^{42}$

Dependent Variable and Model Specification We use the government's change in vote share from the previous election to quantify incumbent electoral success. We aim to determine whether governments are penalized at the ballot box for the occurrence of a general strike during their tenure and whether strikes magnify penalties for incumbents if social expenditure as a percentage of GDP declines relative to the previous electoral cycle. While we control for partisanship in our models, we do not find significant interactions between strikes, welfare retrenchment, and the partisan incumbent dummies in influencing changes in incumbent vote share. Therefore, our results suggest that blame attribution impacts all types of incumbents regardless of the party leading the executive. For coalition governments, we define the incumbent as the party that holds the prime ministership, in line with findings that voters often lack knowledge about cabinet composition in coalition governments ${ }^{43}$ and that voters tend to assign policy responsibility to the party with agenda-setting power and the largest vote share, ${ }^{44}$ which generally is the party of the prime minister. ${ }^{45}$ However, as detailed below, we also use the change in incumbent vote share (since the previous election) for the three largest parties in the executive as a robustness check.

We utilized a quasi-first-difference OLS, fixed effects panel estimator with country clustered standard errors to gauge the impact of general strikes on incumbent vote shares - all of our variables are differenced except unemployment and the incumbent's vote share in the previous election (we discuss below why these variables are not differenced). The baseline regression model is as follows:

$$
\begin{aligned}
\Delta \mathrm{VS}_{\mathrm{i}, \mathrm{t}}= & \alpha_{\mathrm{i}, \mathrm{t}}+\beta_{1} \mathrm{VS}_{\mathrm{i}, \mathrm{t}-1}+\beta_{2} \operatorname{LeftIncb}_{\mathrm{i}, \mathrm{t}}+\beta_{2} \text { RightIncb }_{\mathrm{i}, \mathrm{t}}+\beta_{4}\left(\mathrm{GS}_{\mathrm{i}, \mathrm{t}}\right)+\beta_{5}\left(\mathrm{SP}_{\mathrm{i}, \mathrm{t}}\right) \\
& +\beta_{6}\left(\operatorname{Leg}_{\mathrm{i}, \mathrm{t}}\right)+\Sigma \beta_{\mathrm{k}} \mathrm{X}_{\mathrm{k}, \mathrm{i}, \mathrm{t}}+\Sigma \beta_{\mathrm{m}} \mathrm{Z}_{\mathrm{m}, \mathrm{i}, \mathrm{t}}+\varepsilon_{\mathrm{i}, \mathrm{t}}
\end{aligned}
$$

$\Delta \mathrm{VS}_{\mathrm{i}, \mathrm{t}}$ is the (percentage point) change in vote share for the incumbent in country $i$ at election year $t, \mathrm{VS}_{\mathrm{i}, \mathrm{t}-1}$ is the incumbent party's vote share in country $i$ after the previous election, LeftInc $b_{i, t}$ is a dummy variable indicating whether the incumbent is a left party, RightIncb $b_{i, t}$ is a dummy variable indicating whether the incumbent is a right or liberal party (hence the baseline for the model is a Center/Christian Democratic party ${ }^{46}$ ), and $\mathrm{GS}_{\mathrm{i}, \mathrm{t}}, \mathrm{SP}_{\mathrm{i}, \mathrm{t}}$, and $\mathrm{Leg}_{\mathrm{i}, \mathrm{t}}$ are the general strike, social pacts, and strike-free unilateral legislation variables, respectively, in one of the two manifestations defined above. We include the incumbent's vote share in the previous election to discern whether incumbents suffer a "cost of governing" penalty resulting from their 
position at the helm of government. ${ }^{47}$ Because the previous vote share of an incumbent is strongly associated with the type of government in power (i.e., single-party majorities have larger vote shares in the previous election than parties ruling in minority or coalition governments) we do not control for government type.

It is important to emphasize that election years can be preceded by a general strike, a social pact, and strikeless unilateral reform (the three events are not mutually exclusive) and hence their beta coefficients cannot be interpreted relative to each other as they would be with a standard multi-categorical dummy. However, these three dummies are mutually exclusive of our fourth scenario of welfare reform-no reform-which serves as our baseline category, en masse, to these three welfare reform scenarios. Hence, our strikes, social pacts, and strikeless legislation variables below are interpreted relative to electoral cycles without reform. We anticipate that general strikes will be negatively associated with changes in vote share, compared to electoral cycles without reform. Strikeless unilateral legislation should also possess a negative coefficient given that this event, too, introduces welfare and social policy retrenchment, although we expect its influence may be less than that of a general strike, which adds to the visibility of policy reform. Social pacts should be positively associated with vote share gains or non-significant, relative to electoral cycles without reform, given their use to achieve consensus on governments' contentious proposals. All vote share data and party classifications were taken from Armingeon et al.'s Comparative Political Dataset. ${ }^{48}$

$\Sigma \beta_{\mathrm{k}} X_{\mathrm{k}, \mathrm{i}, \mathrm{t}}$ is a vector of economic controls that includes the average level of unemployment, inflation, and GDP growth during the electoral cycle, as well as the first difference of the three welfare retrenchment proxies (defined above) between the current and previous electoral cycle. ${ }^{49} \mathrm{We}$ include the average level of unemployment rather than the first difference, because declines in unemployment between elections are unlikely to have similar electoral effects at all levels of unemployment (for example, a 2 percent decline in unemployment may be differently rewarded by an electorate that is facing a 15 percent rate than that facing a 5 percent unemployment rate). We purposefully exclude other budgetary measures, such as net government borrowing and public debt, from our analysis given their correlation with changes in social spending. We anticipate that both inflation and unemployment will be negatively associated with changes in an incumbent's vote share, while GDP growth should be positively associated with changes in the vote share. Changes in social expenditure (or the social insurance generosity index) between electoral cycles should be positively associated with vote share changes: if welfare generosity increases/decreases, governments are likely to be rewarded/penalized at the ballot box. Inflation and GDP growth data were taken from the OECD. Unemployment, social benefits, and social transfers-in-kind expenditure data were taken from the EU's ECOFIN's Annual Macroeconomic Database (AMECO).

$\Sigma \beta_{\mathrm{m}} Z_{\mathrm{m}, \mathrm{i}, \mathrm{t}}$ is a vector of interaction terms between the first difference of our welfare retrenchment measure on the one hand and general strikes, social pacts, and strikeless unilateral legislation on the other (recall that these three reform events are 10 
interpreted relative to the no-reform baseline category). ${ }^{50} \mathrm{We}$ anticipate that the interaction between general strikes and changes in social expenditure/welfare generosity should have a positive effect upon changes in incumbent vote share: vote share declines that accompany reductions in social spending/welfare generosity should be further magnified in the presence of a general strike that highlights the severity of reform. The interaction between social pacts and changes in social expenditure/welfare generosity should have a negative effect on changes in incumbent vote share: the negative electoral impact of welfare retrenchment should be mitigated if it occurs via (consensus-based) social pacts. Finally, the interaction between strikeless unilateral legislation and changes in social expenditure/welfare generosity should be positive or insignificant. For a given reduction in social spending/welfare generosity, incumbents may be further penalized electorally if they push reforms through unilaterally. However, if these unilateral reforms are not highly visible (due to the absence of general strikes), they may not introduce additional electoral-losses.

Autocorrelation problems within panels were controlled for by selecting the change in vote share as the dependent variable, as indicated by insignificant Wooldridge statistics for (first-order) autocorrelation. ${ }^{51}$ Given significant evidence for panel heteroskedasticity within the baseline models, ${ }^{52}$ robust standard errors, clustered by country, were used. We opted for country-clustered standard errors, which provide more conservative standard errors than panel-corrected standard errors. ${ }^{53}$ We included country fixed effects in our main models to control for omitted country-specific variables (such as electoral systems, systems of capitalism, and welfare regimes) that fail to exhibit variation over time.

Additional Robustness Checks We run three types of robustness checks, which we do not present here due to space constraints, but which we provide in (online) Appendix A. First, we run our models with random effects to address concerns about the use of fixed effects with independent variables that display little variation over time across all or some panels ${ }^{54}$ (results in Tables A1 and A2). Second, we employ several jack-knife tests, excluding prototypical cases that may drive our results (results also in Tables A1 and A2). Contrary to social pacts and strikeless legislation for which variation across our sample countries is more evenly distributed, general strikes are more concentrated in Southern Europe; hence our results may be dominated by political effects unique to this region. To determine whether our results are robust, we exclude the highly strike-prone Southern European countries (Greece, Italy, Spain, and Portugal) one by one to see if their inclusion drives our results. We also conduct regressions, omitting the years of the global financial crisis and subsequent debt crisis (2008-2012) as this period was marked by a high frequency of strike activity and high government turnover. Finally, we ran our (interactive) regression models using the change in incumbent vote share for the three largest parties in the executive as our dependent variable (if the incumbent rules in coalition), rather than vote share changes for the prime minister's party only (results in Table A3). In all our robustness checks, our results are highly resilient. In addition to these three robustness checks, we also 
test whether the clarity of responsibility hypothesis applies to our argument in supplementary regressions (i.e., do single-party majority governments incur greater vote share losses than coalition/minority governments if a general strike occurs alongside with welfare retrenchment?), but the (triple) interaction terms were non-significant (results in Table A4).

\section{Results}

Table 1 presents the results for the baseline models using changes in social expenditure as a proxy for retrenchment. Whether codified as binary or as its proximity to the nearest election, general strikes display a significant association with declining vote shares for incumbent governments within three of four models in Table 1 (for model III, significance is just below a 90 percent confidence interval) and in thirteen of fourteen supplementary regressions in Appendix A. Even when controlling for changes in social spending, the presence of a general strike is associated with a 2.2 percentage point decline in incumbent vote share, relative to electoral cycles with no reform (Model I, Table 1). Moreover, the electoral impact of strikes becomes more severe the closer they are to a general election; a general strike that occurs one-quarter of the way into an incumbent's term is associated with a 1.5 percentage point reduction in vote share, while a strike that occurs three-quarters into an electoral cycle is associated with a 4.6 percentage point vote share decline, suggesting that governments can blunt the electoral penalties associated with general strikes if they push unpopular reforms earlier in their term (Model IV, Table 1). These significantly negative results for strikes' main effect within the interactive models are consistent when we use Scruggs' et al.'s generosity index as the proxy for welfare retrenchment (see Table 2), but are significant in only one of two models where the social expenditure residual is used to proxy retrenchment (model III, Table 2).

The presence of social pacts, on its own, does not demonstrate consistency in being significantly associated with increases in incumbent vote shares (note the lack of significance of pacts' main effect in Models I, III, and IV, Table 1, and in the supplementary regressions in online Appendix A). In the five of the eight models where pacts' main effect is significant, however, it is associated with significant vote share increases for the incumbent, as expected. Strikeless unilateral legislation on its own displays no significant direct association with changes in vote share, indicated by its insignificant main effect, in seven of eight models presented in Tables 1 and 2.

The interaction models (Models II and IV, Table 1, and Models I-IV, Table 2) suggest that general strikes also magnify electoral penalties associated with social expenditure/generosity decline. Starting with results in Table 1, in the non-interactive models, changes in social spending between electoral cycles display no significant correlation with changes in incumbent vote share. Rather, results in Models II and IV (Table 1) indicate that the main effect of changes in social expenditure on incumbent vote shares only becomes significant when interactions with strikes, pacts, and strikeless 
Table 1 Results for Incumbents' Change in Vote Share

\begin{tabular}{|c|c|c|c|c|}
\hline & I & II & III & IV \\
\hline Previous Vote Share & $\begin{array}{c}-0.3066^{* *} \\
(0.109)\end{array}$ & $\begin{array}{c}-0.3116^{* * *} \\
(0.104)\end{array}$ & $\begin{array}{c}-0.3174 * * \\
(0.110)\end{array}$ & $\begin{array}{c}-0.3099 * * \\
(0.114)\end{array}$ \\
\hline Left Incumbent ( $1=$ yes $)$ & $\begin{array}{c}-0.9964 \\
(1.377)\end{array}$ & $\begin{array}{c}-0.9747 \\
(1.407)\end{array}$ & $\begin{array}{c}-0.9472 \\
(1.309)\end{array}$ & $\begin{array}{c}-0.9586 \\
(1.126)\end{array}$ \\
\hline Right Incumbent ( $1=$ yes $)$ & $\begin{array}{l}1.5504 \\
(1.616)\end{array}$ & $\begin{array}{l}1.6783 \\
(1.860)\end{array}$ & $\begin{array}{l}1.6769 \\
(1.604)\end{array}$ & $\begin{array}{l}1.7142 \\
(1.777)\end{array}$ \\
\hline $\begin{array}{c}\text { General strikes during } \\
\text { tenure }(1=\text { yes }) \\
\text { Accepted pacts during } \\
\text { tenure }(1=\text { yes }) \\
\text { Strikeless unilateral legislation } \\
(1=y e s)\end{array}$ & $\begin{array}{c}-2.2139 * * \\
(0.980) \\
2.0017 \\
(1.339) \\
-0.8477 \\
(1.087)\end{array}$ & $\begin{array}{c}-3.4975 * * * \\
(1.131) \\
3.0189 * \\
(1.586) \\
-0.0212 \\
(1.036)\end{array}$ & & \\
\hline $\begin{array}{c}\text { Strike Proximity (fraction } \\
\text { into an incumbent's term) } \\
\text { Pact Proximity (fraction } \\
\text { into an incumbent's term) } \\
\text { Legislation Proximity (fraction } \\
\text { into an incumbent's term) }\end{array}$ & & & $\begin{array}{l}-3.5766 \\
(2.451) \\
1.9764 \\
(2.120) \\
-1.898 \\
(1.490)\end{array}$ & $\begin{array}{c}-6.1500 * * \\
(2.491) \\
2.3467 \\
(2.390) \\
-0.0608 \\
(1.905)\end{array}$ \\
\hline $\begin{array}{c}\text { First-difference in social } \\
\text { expenditure } \dagger\end{array}$ & $\begin{array}{l}0.3389 \\
(0.243)\end{array}$ & $\begin{array}{l}1.4308 * * * \\
(0.453)\end{array}$ & $\begin{array}{l}0.3625 \\
(0.229)\end{array}$ & $\begin{array}{l}1.3135 * * * \\
(0.306)\end{array}$ \\
\hline Inflation & $\begin{array}{l}0.2416 * \\
(0.136)\end{array}$ & $\begin{array}{c}0.3189 * \\
(0.175)\end{array}$ & $\begin{array}{l}0.1828 \\
(0.115)\end{array}$ & $\begin{array}{l}0.2209 \\
(0.132)\end{array}$ \\
\hline GDP Growth & $\begin{array}{c}1.9919 * * * \\
(0.405)\end{array}$ & $\begin{array}{c}1.9899 * * * \\
(0.356)\end{array}$ & $\begin{array}{c}1.9799 * * * \\
(0.404)\end{array}$ & $\begin{array}{c}1.8935^{* * *} \\
(0.427)\end{array}$ \\
\hline Unemployment & $\begin{array}{l}0.1596 \\
(0.238)\end{array}$ & $\begin{array}{c}0.163 \\
(0.224)\end{array}$ & $\begin{array}{l}0.1379 \\
(0.245)\end{array}$ & $\begin{array}{l}0.0854 \\
(0.233)\end{array}$ \\
\hline $\begin{array}{c}\text { Strike * First-difference in social } \\
\text { expenditure } \\
\text { Pacts * First-difference in social } \\
\text { expenditure }\end{array}$ & & $\begin{array}{c}1.5123 * * \\
(0.681) \\
-1.2657 * * \\
(0.461)\end{array}$ & & $\begin{array}{c}2.9342 * * \\
(1.178) \\
-1.9465^{* * *} \\
(0.634)\end{array}$ \\
\hline $\begin{array}{c}\text { Legislation } * \text { First-difference in social } \\
\text { expenditure }\end{array}$ & & $\begin{array}{c}-1.2310^{*} \\
(0.687)\end{array}$ & & $\begin{array}{c}-2.1498 * * \\
(0.869)\end{array}$ \\
\hline Constant & $\begin{array}{l}0.3914 \\
(3.750)\end{array}$ & $\begin{array}{l}-0.7961 \\
(3.388)\end{array}$ & $\begin{array}{l}1.5392 \\
(3.914)\end{array}$ & $\begin{array}{l}1.1495 \\
(4.126)\end{array}$ \\
\hline Observations & 115 & 115 & 115 & 115 \\
\hline$F$-statistic & $9.81 * * *$ & $25.19 * * *$ & $7.00 * * *$ & $21.74 * * *$ \\
\hline R-squared (within) & 0.441 & 0.480 & 0.430 & 0.474 \\
\hline
\end{tabular}

$\uparrow$ Social expenditure includes spending on social benefits and transfers-in-kind as a percentage of GDP. Dependent variable is the change in the incumbent's vote share between the current and previous election. Model used is a quasi-first-differenced fixed (country) effects OLS estimator of election years from 1980 to 2012 for 16 countries (EU15 plus Norway). Robust standard errors (clustered by country) are in parenthesis. $*, * *$, and $* * *$ indicate significance on a $90 \%, 95 \%$ and $99 \%$ confidence levels. 
Table 2 Robustness Checks for Incumbents' Change in Vote Share (different proxies for welfare retrenchment)

\begin{tabular}{|c|c|c|c|c|}
\hline \multirow[b]{2}{*}{ Welfare Retrenchment Proxy } & \multicolumn{2}{|c|}{ Scruggs' Generosity Index } & \multicolumn{2}{|c|}{ Social Expenditure Residual } \\
\hline & I & II & III & IV \\
\hline Previous Vote Share & $\begin{array}{c}-0.2034 * * * \\
(0.056)\end{array}$ & $\begin{array}{c}-0.2000 * * * \\
(0.056)\end{array}$ & $\begin{array}{c}-0.2396^{* *} \\
(0.098)\end{array}$ & $\begin{array}{c}-0.2840 * * \\
(0.105)\end{array}$ \\
\hline Left Incumbent ( $1=y e s)$ & $\begin{array}{l}0.5136 \\
(1.235)\end{array}$ & $\begin{array}{l}0.0726 \\
(1.175)\end{array}$ & $\begin{array}{l}-2.3984 \\
(1.603)\end{array}$ & $\begin{array}{c}-1.4773 \\
(1.411)\end{array}$ \\
\hline Right Incumbent $(1=y e s)$ & $\begin{array}{l}1.9795 * \\
(0.930)\end{array}$ & $\begin{array}{l}1.7014 \\
(1.077)\end{array}$ & $\begin{array}{l}0.8687 \\
(1.515)\end{array}$ & $\begin{array}{l}1.6423 \\
(1.386)\end{array}$ \\
\hline General strikes during & $-2.1195^{* *}$ & & $-2.0964 * *$ & \\
\hline tenure $(1=y$ es $) \ddagger$ & $(0.893)$ & & $(0.845)$ & \\
\hline Accepted pacts during & $2.4953 *$ & & $2.5272 *$ & \\
\hline tenure $(1=$ yes $) \ddagger$ & (1.204) & & $(1.252)$ & \\
\hline $\begin{array}{c}\text { Strikeless unilateral legislation } \\
\qquad(1=y e s) \ddagger\end{array}$ & $\begin{array}{l}2.1909 * \\
(1.202)\end{array}$ & & $\begin{array}{c}-1.4152 \\
(1.160)\end{array}$ & \\
\hline Strike Proximity ( fraction & & $-9.4971 * * *$ & & -3.4735 \\
\hline $\begin{array}{l}\text { into an incumbent's term) } \\
\text { Pact Proximity (fraction }\end{array}$ & & $\begin{array}{c}(1.553) \\
3.5369 * * *\end{array}$ & & $\begin{array}{c}(2.814) \\
3.7044 * *\end{array}$ \\
\hline into an incumbent's term) & & $(0.860)$ & & $(1.560)$ \\
\hline Legislation Proximity ( fraction & & 1.7358 & & -2.3991 \\
\hline into an incumbent's term) & & $(1.651)$ & & $(1.433)$ \\
\hline First-difference in Scruggs & 0.8055 & 0.5617 & & \\
\hline social insurance generosity index & $(0.961)$ & $(0.951)$ & & \\
\hline Social expenditure residual $\dagger \dagger$ & & & $\begin{array}{l}-0.271 \\
(0.609)\end{array}$ & $\begin{array}{c}-0.1161 \\
(0.512)\end{array}$ \\
\hline Inflation & $\begin{array}{c}0.2170 * * \\
(0.091)\end{array}$ & $\begin{array}{l}0.1540 * \\
(0.083)\end{array}$ & $\begin{array}{l}0.1559 \\
(0.155)\end{array}$ & $\begin{array}{l}0.0832 \\
(0.148)\end{array}$ \\
\hline GDP Growth & $\begin{array}{l}0.8166^{* * *} \\
(0.279)\end{array}$ & $\begin{array}{l}0.8653 * * * \\
(0.266)\end{array}$ & $\begin{array}{l}1.5402 * * * \\
(0.346)\end{array}$ & $\begin{array}{c}1.4442 * * * \\
(0.330)\end{array}$ \\
\hline Unemployment & $\begin{array}{l}0.1118 \\
(0.200)\end{array}$ & $\begin{array}{l}0.0836 \\
(0.197)\end{array}$ & $\begin{array}{l}0.2645 \\
(0.250)\end{array}$ & $\begin{array}{l}0.2637 \\
(0.244)\end{array}$ \\
\hline Strike * Welfare retrenchment & $7.3684 * *$ & $17.7140 * * *$ & $0.7003^{*}$ & $1.1039^{*}$ \\
\hline Measure & $(2.815)$ & $(3.969)$ & $(0.374)$ & $(0.623)$ \\
\hline Pacts $*$ Welfare retrenchment & 1.1994 & 1.0806 & $-0.7823 *$ & $-2.1920 * *$ \\
\hline Measure & $(2.463)$ & $(5.579)$ & $(0.372)$ & $(0.868)$ \\
\hline Legislation $*$ Welfare retrenchment & -1.1079 & -1.4232 & 0.6306 & 0.7084 \\
\hline Measure & $(2.718)$ & $(4.676)$ & $(0.413)$ & $(0.547)$ \\
\hline Constant & $\begin{array}{l}-1.5702 \\
(2.935)\end{array}$ & $\begin{array}{l}-0.0921 \\
(2.983)\end{array}$ & $\begin{array}{c}-0.3785 \\
(4.067)\end{array}$ & $\begin{array}{l}1.3523 \\
(3.876)\end{array}$ \\
\hline Observations & 118 & 118 & 119 & 119 \\
\hline$F$-statistic & $219.03 * * *$ & $77.70 * * *$ & $9.97 * * *$ & $8.65 * * *$ \\
\hline R-squared (within) & 0.264 & 0.278 & 0.416 & 0.405 \\
\hline
\end{tabular}

\$Strikes, pacts, and strikeless legislation in Models I and II only pertain to pensions and welfare (as the Scruggs index only focuses on social insurance generosity).

$\dagger \uparrow$ Social expenditure residual is the residual from social expenditure (on benefits and transfers-in-kind) as a percentage of GDP regressed on unemployment, real GDP growth, and the proportion of the elderly population. Dependent variable is the change in the incumbent's vote share between the current and previous election. Model used is a quasi-first-differenced fixed (country) effects OLS estimator of election years from 1980 to 2012 for 16 countries (EU15 plus Norway). Robust standard errors (clustered by country) are in parenthesis. $*, * *$, and $* * *$ indicate significance on a $90 \%, 95 \%$ and $99 \%$ confidence levels, respectively. 
legislation are included. Taking results from Model II, Table 1, a 1-percentage point decline in social expenditure as a percent of GDP between electoral cycles in the absence of general strikes or pacts (i.e., welfare retrenchment's main effect) is associated with a 1.4 percentage point reduction in incumbent vote share. If a general strike occurs during an electoral cycle, however, the electoral penalty associated with a one-percentage point decline in social expenditure is magnified to almost three percentage points (strikes' magnification of the impact of social spending cuts on incumbent vote share loss is displayed visually in Figure 2). In our models that provide alternative measures of welfare state retrenchment (see Table 2), as well as our supplementary regressions in Appendix A, strikes' magnification of the negative impact of welfare state decline on incumbents' vote shares remains consistently significant.

In contrast, if a social pact occurs during an electoral cycle, the vote share penalty associated with a one percentage point decline in social expenditure is associated with a mere 0.16 percentage point drop in vote share (model II, Table 1). Pacts'

Figure 2 Interaction Effects between General Strikes and Declines in Social Spending (as a percentage of GDP) on Incumbent Vote Share Changes

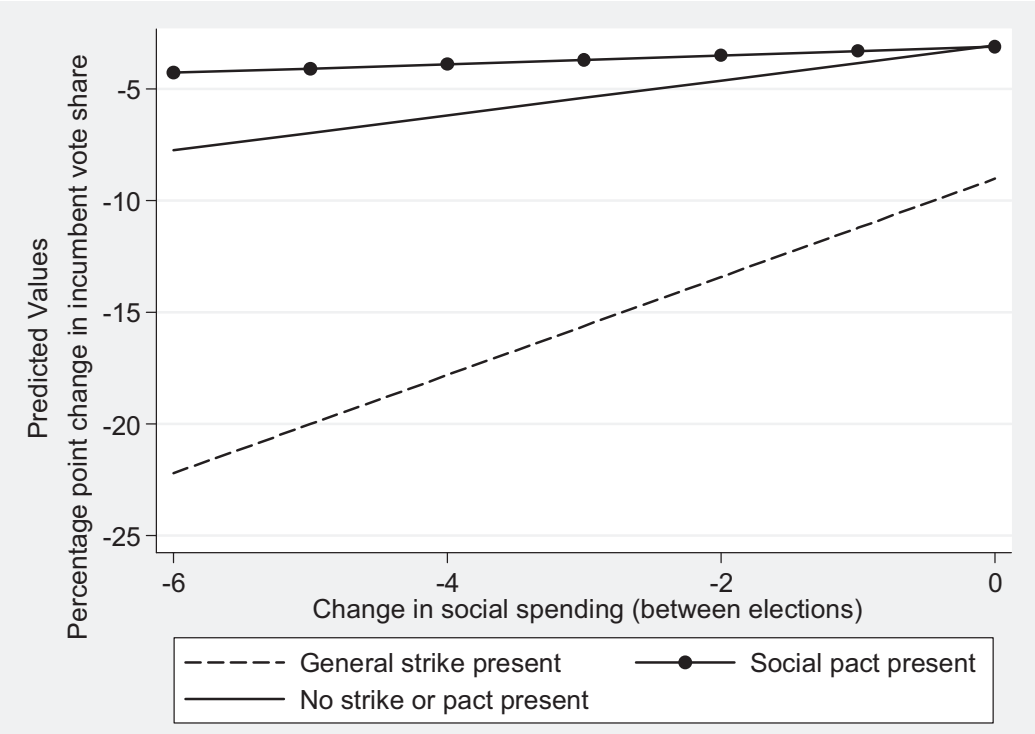

Change in social spending is the first-difference in social spending to GDP ratios between elections. Note: Results produced from regression output in Model II, Table 1. Graphic produced via STATA's "predxcon" command ("predxcon" does not graph confidence intervals when interaction categories are specified). 
mitigation of social expenditure decline on incumbents' vote shares (shown visually in Figure 2) is not as robust to alternative measures of welfare retrenchment as strikes are. In Table 2, pacts also (significantly) mitigate the negative impact of welfare retrenchment on incumbent vote share if retrenchment is measured as the social expenditure residual (models III and IV). However, (pension and welfare) pacts' mitigating impact does not maintain its significance if the Scruggs index is used to measure retrenchment (models I-II, Table 2). Finally, strikeless unilateral reform legislation also, unexpectedly, appears to mitigate the negative electoral effects of declines in social expenditure (models II and IV, Table 1). This may be due to the fact that such under-the-radar reforms may produce economy-improving effects by the next election. However, strikeless unilateral reforms' mitigation of welfare decline on incumbent vote share loss is not robust when alternative retrenchment proxies are used (see Table 2).

The enhancing and offsetting effects of strikes and pacts on changes in social spending are also influenced by timing (Model IV, Table 1; models II and IV, Table 2). If the most recent strike to the current election occurs one-quarter into an incumbent's term, the electoral penalty associated with a 1 percentage point decline in social spending (as a percentage of GDP) is a 2 percentage point decline in vote share, compared to a 3.5 percentage point vote share decline if the strike occurs threequarters into an incumbent's term. In contrast, if the most recent social pact to a general election occurs one-quarter into an incumbent's term, the electoral penalty associated with one percentage point decline in social spending (as a percentage of GDP) is a 0.83 percentage point drop in vote share, while if the most recent pact occurs three-quarters into an incumbent's term, the incumbent party witnesses a 0.15 percentage point increase in vote share. When using alternative measures of welfare retrenchment, interaction terms using the proximity manifestations are highly robust in the case of general strikes (Models II and IV in Table 2), but not in the case of social pacts when the Scruggs index is used (model II, Table 2). As with the binary manifestation, the proxy measure of strikeless unilateral legislation also mitigates the impact of social spending decline on incumbent vote share loss, but this impact lacks significance when other measures of retrenchment are used (models II and IV, Table 2).

Regarding the other variables, GDP growth was significantly associated with an increase in vote share for the incumbent government, as expected. Inflation was associated with an increase in vote share for the incumbent (contrary to what was expected, although significance was weak and only emerged in four of our eight models shown), while unemployment failed to exhibit significant effects. The incumbent's vote share prior to the election was significantly associated with declines in electoral vote shares, indicating a "negative incumbency bias." 55 Finally, we did not find any evidence for a partisan effect: the main governing party neither lost from strikes nor gained from pacts as a result of belonging to a particular party family, nor did we witness significant interactions between strikes, changes in social spending, and partisanship (results not shown). 


\section{Conclusion}

Unlike industrial (economic) strikes, which primarily involve union members and workplace issues, general strikes serve as protest vehicles against social policy reforms, the impact of which is more universal. General strikes target large segments of the electoral base beyond union members. Even if large numbers of voters not affiliated with a union fail to participate in the strikes themselves, these instances of protest may motivate them to penalize incumbent governments at the ballot box in the subsequent election. Such political responses by voters are important for unions' strategies. They suggest that despite membership decline and the costs of organizing general strikes, unions may be able to influence incumbents' tenure by turning public opinion against governments and their policies via strike action.

Our results indicate that general strikes are of political, and especially electoral, importance, even during periods of union decline. While unions' capacity to influence issues related to the workplace appears to be decreasing, they have been a significant actor in national politics in Western Europe over the last three decades. They have played a prominent role in negotiating policy reforms through social pacts, but they have also expressed their-as well as many voters'-opposition to other reforms by mobilizing protest through general strikes. Social pacts can serve as tools for blame avoidance, and, according to our results, in promoting consensus among a wider group of political actors they appear to blunt electoral backlash during periods of reductions in social spending. General strikes, however, are tools of blame attribution and have significant repercussions for governments because they heighten public awareness of spending cuts and have the potential to magnify the electoral backlash against retrenchment.

At the same time, we need to interpret our findings with caution. While we attempt to decouple unpopular reforms from general strikes via the inclusion of strikeless unilateral reforms as a benchmark, as well as by controlling for reductions in social spending and its interaction with general strikes, we lack precise data that would allow us to completely distinguish the electoral effect of the unpopular reforms from the effect of the general strike itself. Consistent polling data that reflect voting intentions or evaluations of all reforms and strikes included in our sample are not readily available. Yet, at the same time, voting intentions stated in opinion polls during some point of time in the inter-election period might also change by the time the next election is held and might therefore not reflect actual electoral effects either. Despite our study's limitations, our analysis provides consistent evidence that the vote share of governing parties declines after general strikes occur and that these losses are magnified if welfare retrenchment occurs in-between elections.

Our analysis can provide at least a partial answer to the question of why unions engage in organizing general strikes. Previous research posits that general strikes can be effective in altering policy reforms. Here, we show that general strikes can also exert influence by affecting governments' electoral support. This finding perhaps explains why governments sometimes make concessions in response to general strikes, despite unions' organizational and economic decline. General strikes are costly, not 
just economically, but also politically, and governments have incentives to minimize these costs. As current European governments engage in deep austerity cuts (or as their creditors force them to), general strikes may add further political instability by weakening ruling parties' electoral support.

\section{NOTES}

1. Sabina Avdagic, Martin Rhodes, and Jelle Visser, Social Pacts in Europe: Emergence, Evolution and Institutionalization (Oxford: Oxford University Press, 2011); Anke Hassel, Wage Setting, Social Pacts and the Euro (Amsterdam: Amsterdam University Press, 2006).

2. Alexandre Afonso, Social Concertation in Times of Austerity (Amsterdam: Amsterdam University Press, 2013); Kerstin Hamann, Alison Johnston, Alexia Katsanidou, John Kelly, and Philip H. Pollock, "Sharing the Rewards but Dividing the Costs?: The Electoral Consequences of Social Pacts and Legislative Reform in Western Europe," West European Politics, 38(January 2015), 206-27; Bernhard Ebbinghaus and Anke Hassel, "Striking Deals: Concertation in the Reform of Continental European Welfare States," Journal of European Public Policy, 7 (March 2000), 44-62; Kerstin Hamann and John Kelly, Parties, Elections and Policy Reforms in Western Europe: Voting for Social Pacts (Abingdon: Routledge, 2011); Hassel.

3. John Ahlquist, "Policy by Contract: Electoral Cycles, Parties and Social Pacts, 1974-2000," Journal of Politics, 72 (April 2010), 572-87.

4. Kurt Vandaele, Sustaining or Abandoning Social Peace? Strike Developments and Trends in Europe since the 1990s (Brussels: European Trade Union Institute, Working Paper 2011.05, 2011).

5. Richard Hyman, Strikes, $4^{\text {th }}$ ed. (London: Macmillan, 1989), 17.

6. Kerstin Hamann, Alison Johnston, and John Kelly, "Unions against Governments: Explaining General Strikes in Western Europe, 1980-2006," Comparative Political Studies, 46 (September 2013a), 1030-57; Johannes Lindvall, "Union Density and Political Strikes," World Politics, 65 (July 2013), 539-69.

7. Hamann, Johnston, and Kelly, 2013a, updated by the authors.

8. Ibid.

9. Engelbert Stockhammer, Why Have Wage Shares Fallen? A Panel Analysis of the Determinants of Functional Income Distribution (Geneva: International Labour Office, Conditions of Work and Employment Series, No. 35, 2013).

10. Pepper Culpepper and Aidan Regan, "Why Don't Governments in Europe Need Trade Unions Anymore?: The Death of Social Pacts in Ireland and Italy," Socio-Economic Review, 12 (October 2014), $723-45$.

11. To illustrate the economic costs, the Spanish general strike of March 28, 2012 resulted in a decline of $16 \%$ in energy consumption for the day (Raphael Minder, "General Strike Hobbles Spain," New York Times, Mar. 29, 2012). Regarding political cost, it seems that governments anticipate their political and economic costs when initiating reforms. Spanish Prime Minister Rajoy, for example, commented off the record that he expected that his labor market reforms would "cost" him a general strike (El País, Jan. 31, 2012).

12. Lindvall.

13. Hamann, Johnston, and Kelly, 2013a.

14. Kerstin Hamann, Alison Johnston, and John Kelly, "Striking Concessions from Governments: Explaining the Success of General Strikes in Western Europe, 1980-2009," Comparative Politics, 46 (October 2013b), 23-41.

15. Ahlquist; Hamann and Kelly, 2011.

16. Clem Brooks and Jeff Manza, "Why Do Welfare States Persist?" Journal of Politics, 68 (November 2006), 816-27; Paul Pierson, "The New Politics of the Welfare State," World Politics, 48 (January 1996), $143-79$.

17. Staffan Kumlin, "The Welfare State: Values, Policy Preferences, and Performance Evaluations," in Russell J. Dalton and Hans-Dieter Klingemann, eds., The Oxford Handbook of Political Behavior (Oxford: Oxford University Press, 2007), 362-82; Staffan Kumlin, "Overloaded or Underdetermined? European Welfare States in the Face of Performance Dissatisfaction," in Stefan Svallfors, ed., The Political Sociology of the Welfare State: Institutions, Social Cleavages, and Orientations (Stanford: Stanford University Press, 2007), 80-116.

18. For example, Steven D. Levitt and James M. Snyder, "The Impact of Federal Spending on House Election Outcomes," Journal of Political Economy, 105 (February 1997), 30-53. 
19. Larry M. Bartels, Unequal Democracy: The Political Economy of the New Gilded Age (New York and Princeton: Russell Sage Foundation and Princeton University Press, 2008).

20. Kees van Kersbergen and Barbara Vis, Comparative Welfare State Politics: Developments, Opportunities, and Reform (New York: Cambridge University Press, 2014).

21. Klaus Armingeon and Nathalie Giger, "Conditional Punishment: A Comparative Analysis of the Electoral Consequences of Welfare State Retrenchment in OECD Nations, 1980-2003," West European Politics, 31 (April 2008), 558-80.

22. Pierson, 1996; Paul Pierson, "Irresistible Forces, Immovable Objects: Post-industrial Welfare States Confront Permanent Austerity," Journal of European Public Policy, 5 (December 1998), 539-60.

23. Georg Wenzelburger, "Political Strategies and Fiscal Retrenchment: Evidence from Four Countries," West European Politics, 34 (November 2011), 1151-84.

24. Hamann, Johnston, and Kelly, 2013a, 2013b.

25. Unfortunately, consistent data for turnout at general strikes for all of our cases are not available; we therefore do not include an "intensity" variable in our analysis.

26. Brooks and Manza.

27. Richard Nadeau, Michael S. Lewis-Beck, and Éric Bélanger, "Economics and Elections Revisited," Comparative Political Studies, 46 (May 2013), 562.

28. Armingeon and Giger, 560.

29. Hanspeter Kriesi, "The Political Consequences of the Financial and Economic Crisis in Europe: Electoral Punishment and Popular Protest," Swiss Political Science Review, 18 (October 2012), 520.

30. Ibid, 520 .

31. Hanspeter Kriesi, "The Political Consequences of the Economic Crisis in Europe: Electoral Punishment and Popular Protest," in Nancy Bermeo and Larry M. Bartels, eds., Mass Politics in Tough Times: Opinions, Votes, and Protest in the Great Recession (New York: Oxford University Press, 2014), 297-333.

32. To illustrate, a study on the 2007 election in Australia found that a union campaign against the government's Work Choices program "increased the salience of industrial relations to voters, that union activism jumped in the lead-up to the election, and that unionized voters voted against the government in record numbers" (Shaun Wilson and Benjamin Spies-Butcher, "When Labour Makes a Difference: Union Mobilization and the 2007 Federal Election in Australia," British Journal of Industrial Relations, 49 (June 2011), 306). This logic also applies to economic voting: Michael Lewis-Beck, Nicholas F. Martini, and D. Roderick Kiewiet, "The Nature of Economic Perceptions in Mass Publics," Electoral Studies, 32 (September 2013), 524-28 find that voters who perceive that the economy has worsened are more likely to vote against the incumbent than those who do not hold that belief. General strikes can increase issue salience and sway vote choices.

33. Ahlquist (2010) finds that this holds for social pacts.

34. Data, replication commands, graphical appendices, and Appendix A can be found at: https://sites. google.com/site/dralisonljohnston/research.

35. We exclude three strikes from our analysis as they are not related to the issues of interest: two strikes against the Iraq War and one against moving the date for Labor Day in Greece. We thus include 114 strikes in our analysis.

36. General strike frequencies (i.e. the number of general strikes per year in an electoral cycle) were zeroskewed. For those election cycles where general strikes occurred, frequencies rarely exceeded one strike per year (only 9 of the 38 electoral cycles that had general strikes had strike frequencies higher than one per year). We therefore opted to condense this skew into a binomial distribution.

37. Ahlquist, 2010.

38. Lyle Scruggs, Detlef Jahn, and Kati Kuitto, Comparative Welfare Entitlements Dataset 2. Version 2014-03 (University of Connecticut \& University of Greifswald, 2014).

39. We only consider social pacts on contentious reforms that have been accepted by all actors, most importantly unions. We do not consider social pact proposals by governments that are rejected by unions as these cases fail to adequately involve union input on policy reform.

40. Ebbinghaus and Hassel; Hassel.

41. Hamann and Kelly.

42. We also consulted the ICTWSS database (Visser 2011) but owing to its significant underreporting of pacts in several countries, notably Spain, we have not relied on it exclusively. Jelle Visser, ICTWSS: Database on Institutional Characteristics of Trade Unions, Wage Setting, State Intervention and Social Pacts in 34 Countries between 1960 and 2007, Version 3.0 (Amsterdam: Institute for Advanced Labour Studies), http://www.uva-aias.net/208, accessed 22 January 2013. 
43. David Fortunato and Randolph T. Stevenson, "Performance Voting and Knowledge of Cabinet Composition," Electoral Studies, 32 (September 2013), 517-23.

44. Raymond M. Duch and Randolph T. Stevenson, "Voter Perceptions of Agenda Power and Attribution of Responsibility for Economic Performance," Electoral Studies, 32 (September 2013), 512-16.

45. See Christopher Anderson, "Economic Voting and Political Context: A Comparative Perspective," Electoral Studies, 19 (June 2000), 151-70.

46. While we do not present these results here, our partisan results remain unchanged if we measure partisanship via a left-incumbent dummy only, consolidating center/CD and right parties into one partisan category.

47. See Peter Nannestad and Martin Paldam, "The Cost of Ruling: A Foundation Stone for Two Theories," in Han Dorussen and Michaell Taylor, eds., Economic Voting (London: Routledge, 2002), 17-44; Joost Van Spanje, "Keeping the Rascals in: Anti-Political-Establishment Parties and Their Cost of Governing in Established Democracies," European Journal of Political Research, 50 (August 2011), 609-35.

48. Kurt Armingeon, David Weisstanner, Sarah Engler, Panajotis Potolidis, and Marlène Gerber, Comparative Political Dataset, 1960-2013 (Bern: Institute of Political Science, University of Bern, 2014).

49. Surprisingly, within our sample, inflation, levels of unemployment, and GDP growth displayed no significant correlation with each other, although the first differences of our unemployment and inflation variables (which we do not use) were significantly correlated with each other and with GDP growth.

50. We also include trade union density as a control, along with its interaction with general strikes, social pacts, and strikeless legislation. Both the main effect of union density and its interaction effects lacked significance. Therefore, we do not present union density within our final regression models.

51. The Wooldridge test statistic from the baseline model (column I, Table 1) was 0.231 (p-value=0.638).

52. The LR chi-squared statistic for Model I, Table 1 was 25.72 (p-value=0.041).

53. William Rogers, "Regression Standard Errors in Clustered Samples," STATA Technical Bulletin, 3 (October 2003), 88-94.

54. This may be a problem for panels in our datasets where no strikes (Denmark, Germany, Ireland, Sweden, and the UK) or pacts (the UK) occurred between 1980 and 2012. See Bernhard Kittel and Hannes Winner, "How Reliable is Pooled Analysis in Political Economy? The Globalization-Welfare State Nexus Revisited," European Journal of Political Research, (March 2005), 269-93.

55. See Nannestad and Paldam; and van Spanje. 